\title{
Analisa Proses Bisnis Satuan Layanan dan Administrasi di Kantor Perwakilan Bank Indonesia Kediri Menggunakan Metode Business Process Improvement (BPI)
}

\author{
Nanang Ismail ${ }^{(1)}$, Ana Komari ${ }^{(2)}$, Sri Rahayuningsih ${ }^{(3)}$ \\ ${ }^{(1)}$ Program Studi Teknik Industri, Fakultas Teknik, Universitas Kadiri \\ Email : n_ismail@bi.go.id ${ }^{(1)}$
}

\begin{abstract}
Abstrak
Kantor Perwakilan Bank Indonesia Kediri adalah menjalankan kebijakan Bank Indonesia salah satu tugasnya menjaga kehandalan sistem pembayaran untuk mendukung pembangunan ekonomi daerah maupun nasional. Jangka panjang yang inklusif dan berkesinambungan, tentunya dalam menjalankan misi tersebut didalamnya didukung oleh suatu tim yang dikenal management intern. Penelitian ini menggunakan metode perbaikan proses bisnis atau Business Process Improvement (BPI). Dilakukan identifikasi gap proses bisnis aktual dengan Surat Edaran yang dikeluarkan oleh Bank Indonesia. Hasil analisis gap akan menjadi masukan untuk analisis aktivitas dimana setiap aktivitas dikelompokkan menjadi RVA, BVA dan NVA. Dilakukan eliminasi pada aktivitas NVA, menstreamlining aktivitas BVA dan melakukan meminimasipada aktivitas RVA. Pada tahap pengumpulan data diperoleh 6 proses bisnis aktual untuk pembayaran kepada pihak ketiga dan penyediaan data, sedangkan untuk pengelolaan bahan bakar diperoleh 2 proses bisnis aktual. Hasil analisa aktivitas menunjukkan terdapat 10 aktivitas RVA, dan 8 aktivitas BVA dan 0 aktivitas NVA. Dari hasil penelitian didapatkan proses bisnis usulan yang telah dilakukan streamlining terdapat peningkatan efisiensi untuk pembayaran kepada pihak ketiga dan penyediaan data untuk stakeholder sebesar 36,67\%, sedangkan untuk pengelolaan bahan bakar minyak sebesar 7.5\%. Perbaikan proses bisnis yang digunakan dalam penelitian ini antara lain upgrading.Proses bisnis usulan menjadi masukan dalam penyusunan SOP.
\end{abstract}

Kata Kunci: Business Process Improvement, Standart Operating Procedure, management intern Abstract

Bank Indonesia Representative Office Kediri is implementing Bank Indonesia policy, one of its tasks is to maintain the reliability of the payment system to support regional and national economic development. An inclusive and sustainable long-term, of course, in carrying out this mission is supported by a team known as internal management. This research uses a business process improvement method (BPI). The actual business process gap is identified with a Circular issued by Bank Indonesia. The results of the gap analysis will be input for activity analysis where each activity is grouped into RVA, BVA and NVA. Elimination of NVA activities is done, streamlining BVA activities and minimizing RVA activities. At the data collection stage, 6 actual business processes are obtained for payments to third parties and data provision, while for fuel management 2 actual business processes are obtained. The results of the activity analysis showed that there were 10 RVA activities, and 8 BVA activities and 0 NVA activities. From the research results obtained that the business processes that have been streamlined have increased efficiency for payments to third parties and the provision of data for stakeholders by $36.67 \%$, while for fuel management by $7.5 \%$. Business process 
improvements used in this study include upgrading. Proposed business processes are input in the preparation of SOPs.

Keyword : Business Process Improvement, Standart Operating Procedure, management intern

\section{Pendahuluan}

Dalam era globalisasi ini, sebuah kantor tidak akan berjalan tanpa data dan informasi. Setiap kegiatan dan pengambilan keputusan di kantor tidak terlepas dari sebuah perencanaan strategis, hal ini terjadi baik di kantor pusat maupun di unit bisnis. Perencanaan Strategis itu sendiri berfungsi untuk memutuskan program-program yang akan dilaksanakan oleh organisasi dan perkiraan jumlah sumber daya yang akan dialokasikan ke setiap program jangka panjang selama beberapa tahun kedepan, hasil dari proses perencanaan strategi berupa dokumen yang dinamakan strategic plan yang berisi informasi tentang program-program beberapa tahun yang akan datang [1], [2]. Kantor Perwakilan Bank Indonesia Kediri adalah salah satu kantor perwakilan dari Bank Indonesia, Misi dari Kantor Perwakilan Bank Indonesia Kediri adalah menjalankan kebijakan Bank Indonesia dalam menjaga stabilitas nilai Rupiah, stabilitas keuangan, efektivitas pengelolaan uang Rupiah dan kehandalan sistem pembayaran untuk mendukung pembangunan ekonomi daerah maupun nasional jangka panjang yang inklusif dan berkesinambungan. Tim yang bertugas yaitu satuan layanan dan administrasi yang mempunyai tugas pokok melakukan administrasi data dan informasi SDM di satuan kerja, mengelola SDM non organik, melakukan perecanaan, pemenuhan, penatausahaan dan pemeliharaan, pengadaan barang dan jasa, termasuk inventaris kantor, alat tulis kantor (ATK) satuan kerja, melakukan fungsi pelaksana anggaran (PA) dan administrasi pajak satuan kerja, melakukan penghitungan, koreksi, penyetoran dan pelaporan pajak Kantor Perwakilan Bank Indonesia, mengelola administrasi perjalanan dinas satuan kerja, melaksanakan tugas-tugas kesekretariatan satuan kerja, mengelola kegiatan protokoler, menyediakan akomodasi, transportasi, perizinan, sarana dan prasarana dalam rangka kegiatan keprotokolan di wilayah kerja, melaksanakan kegiatan operasional pengamanan personil, materil, lingkungan dan acara kedinasan yang diselenggarakan oleh pihak internal dan/atau eksternal di wilayah kerja dan melaksanakan pengelolaan peralatan pengamanan di wilayah kerja [3],[4],[5]. Berdasarkan hasil wawancara yang telah dilakukan kepada kepala Satuan layanan dan administrasi, perencanaan telah dilakukan dalam mendukung misi dan visi Kantor Perwakilan Bank indonesia Kediri terlihat dalam perencanaan penyusunan anggaran yang berdasarkan dari time line yang telah dibuat [6], yang terbagi dalam kegiatan pemeliharaan aset barang maupun aset SDM (Sumber Daya Manusia), pengadaan barang [7], dan kegiatan pengelolaan keprotokolan dan pengamanan serta acara kedinasan yang diselenggarakan oleh pihak internal maupun eksternal di wilayah kerja [8], [9]. Untuk kelancaran dalam melakukan kegiatan yang direncanakan, unit Satuan Layanan dan Administrasi di KPwBI Kediri perlu melakukan perencanaan strategis dengan tetap berpedoman pada aturan yang ditetapkan dari Bank Indonesia agar apa yang telah direncanakan dalam time line yang dibuat dapat terealisasi sesuai target yang direncanakan [10],[11], [12]. Pelaksanaan kegiatan tersebut tentunya tidak terlepas dari permasalahan -permasalahan yang ada, diantaranya staf pelaksana pekerjaan belum optimal dalam menyelesaikan disposisi dari pimpinan dengan target yang ditentukan sebagaimana sesuai dengan ketentuan yang berlaku, salah satu contoh adalah ketepatan pembayaran kepada pihak ketiga [13], [14],[15], yang seharusnya diselesaikan selama 7 hari kerja pada kenyataanya terlaksana lebih 7 hari kerja, atau permintaan data dari kantor pusat tidak dapat segera tersedia data tersebut, hal tersebut dapat berdampak pada reputasi Kantor Perwakilan Bank Indonesia Kediri. 
Tabel 1 Permasalahan dari SLA

\begin{tabular}{|c|c|c|c|c|c|c|}
\hline No. & Permasalahan & Man & Machine & Method & Material & Money \\
\hline 1 & $\begin{array}{l}\text { Mengapa terjadi } \\
\text { pembayaran tidak } \\
\text { sesuai dengan aturan } \\
\text { yang berlaku }\end{array}$ & & & & $\begin{array}{l}\text { Tidak } \\
\text { adanya } \\
\text { reminder } \\
\text { dokumen } \\
\text { yang } \\
\text { didisposisi } \\
\text { ke } \\
\text { pelaksana } \\
\text { tersebut }\end{array}$ & \\
\hline 2 & $\begin{array}{l}\text { Mengapa tidak ada } \\
\text { reminder }\end{array}$ & $\begin{array}{l}\text { Belum } \\
\text { adanya } \\
\text { operator } \\
\text { yang } \\
\text { menginput }\end{array}$ & $\begin{array}{l}\text { Belum } \\
\text { tersedianya } \\
\text { aplikasi yang } \\
\text { mendukung } \\
\text { apabila } \\
\text { vendor } \\
\text { tersebut } \\
\text { belum } \\
\text { terdaftar } \\
\text { sebagai } \\
\text { rekanan }\end{array}$ & & & \\
\hline 3 & $\begin{array}{lr}\text { Mengapa tidak } & \text { ada } \\
\text { operator } & \text { yang } \\
\text { menginput } & \text { dan } \\
\text { aplikasi } & \text { yang } \\
\text { mendukung } & \end{array}$ & & & $\begin{array}{l}\text { Tidak } \\
\text { adanya } \\
\text { SOP } \\
\text { pekerjaan } \\
\text { tersebut }\end{array}$ & & \\
\hline 4 & $\begin{array}{l}\text { Mengapa SOP belum } \\
\text { ada }\end{array}$ & $\begin{array}{l}\text { Pegawai } \\
\text { kurang } \\
\text { memahami } \\
\text { ketentuan } \\
\text { yang } \\
\text { berlaku }\end{array}$ & & & & \\
\hline 5 & $\begin{array}{l}\text { Mengapa pegawai } \\
\text { kurang memahami } \\
\text { ketentuan }\end{array}$ & & $\begin{array}{l}\text { Detail isi } \\
\text { dari } \\
\text { peraturan } \\
\text { belum } \\
\text { tersampaikan }\end{array}$ & & & \\
\hline
\end{tabular}

Tabel 2 Timeline aktual proses penyelesaian pembayaran dan permintaan data

\begin{tabular}{|c|c|c|c|c|c|}
\hline \multirow[t]{2}{*}{ No. } & \multirow[t]{2}{*}{ Nama pekerjaan } & \multicolumn{4}{|c|}{ Minggu } \\
\hline & & 1 & 2 & 3 & 4 \\
\hline 1 & Pembayaran hotel & & & $\mathrm{X}$ & \\
\hline 2 & Pembayaran pemelitharaan aset & & & $\mathrm{X}$ & \\
\hline 3 & Perjalanan dinas & & $\mathrm{X}$ & & \\
\hline 4 & Permintaan data & & & $\mathrm{X}$ & \\
\hline
\end{tabular}

Berdasarkan dari latar belakang dan hasil wawancara tersebut maka akan dilakukan penelitian mengenai "Analisa Proses Bisnis Satuan Layanan dan Administrasi di Kantor Perwakilan Bank Indonesia Kediri menggunakan Metode Business Proses Improvment". 


\section{Metode Penelitian}

Dalam penelitian ini, fokus terhadap proses bisnis Unit Satuan Layanan dan Administrasi pada proses pembayaran pihak ketiga, penyediaan data untuk stakeholder dan pengelolaan bahan bakar dimana untuk mencapai tujuan pembuatan SOP yang lebih efektif dan efisien. Tahap pertama yang dilakukan adalah mengidentifikasi proses bisnis aktual yang terdapat pada Satuan Layanan dan Adminitrasi berdasarkan hasil observasi lapangan dengan wawancara Kepala Satuan Layanan dan Administrasi, staf pegawai di satuan tersebut, Office Boyyang diperbantukan di satuan tersebut. Dan Identifikasi berdasarkan aturan dari Bank Indonesia dilakukan dengan mencari informasi yang berkaitan dengan permasalahan yang dibahas dalam analisa ini. Pencarian dilakukan melalui internet, perpustakaan, sehingga diperoleh referensi yang dapat digunakan untuk mendukung pembahasan analisa ini bertujuan untuk melihat apakah terdapat gap antara kedua hal tersebut dan untuk mengetahui kelemahan/kekurangan/hambatan proses bisnis Satuan Layanan dan Administrasi. Gap yang telah teridentifikasi akan dibuat proses bisnis dengan hasil silang antara proses aktual dengan proses yang sesuai dengan aturan Bank Indonesia.Dengan menggunakan metode Business Prosess Improvement (BPI), akan dilakukan analisa aktivitas dalam setiap proses yang ada dan mengelompokkan kedalam RVA, BVA dan NVA [16],[7],[17],[18]. Tahap kedua adalah melakukan streamlining terhadap hasil analisa aktivitas yang dilakukan dengan menggunakan 13 tools streamlining [17] . Proses bisnis yang sudah sesuai didokumentasikan dengan SOP sehingga SOP yang dirancang sudah sesuai dengan Surat Edaran Bank Indonesia.

\section{Hasil dan Pembahasan}

\subsection{Proses Bisnis Aktual}

Mengacu tugas pokok dan fungsi Satuan Layanan dan Administrasi, serta batasan penelitian sehingga dalam penelitian ini yang akan diteliti hanya dalam penyelesaian pembayaran dengan pihak ketiga, penyediaan data bagi stakeholder, dan pengelolaan bahan bakar [19],[20]. Rata-rata perkiraan waktu aktual yang diperlukan dalam proses pekerjaan penyelesaian kepada pihak ketiga, penyediaan data dan pengelolaan bahan bakar.

Tabel 3 Proses aktual

\begin{tabular}{|c|c|c|}
\hline Proses & Urutan aktivitas & Waktu (jam) \\
\hline \multirow{7}{*}{$\begin{array}{l}\text { Pembayaran } \\
\text { pihak ketiga }\end{array}$} & Dokumen masuk melalui ekspedisi & 1 \\
\hline & Dokumen dimeja kepala perwakilan & 1 \\
\hline & Dokumen dimeja kepala tim & 1 \\
\hline & Dokumen dimeja manajer unit satuan layanan dan administrasi & 3 \\
\hline & Dokumen didistribusikan oleh office & 0,5 \\
\hline & Dokumen di meja staff & 111,5 \\
\hline & Pelaksanaan proses pembayaran & 2 \\
\hline \multirow{7}{*}{$\begin{array}{c}\text { Proses } \\
\text { penyediaan } \\
\text { data }\end{array}$} & Dokumen masuk melalui ekspedisi & 1 \\
\hline & Dokumen dimeja kepala perwakilan & 1 \\
\hline & Dokumen dimeja kepala tim & 1 \\
\hline & Dokumen dimeja manajer unit satuan layanan dan administrasi & 3 \\
\hline & Dokumen didistribusikan oleh office & 0,5 \\
\hline & Dokumen di meja staff & 111,5 \\
\hline & Pelaksanaan penyediaan data & 2 \\
\hline \multirow{3}{*}{$\begin{array}{l}\text { Pengelolaan } \\
\text { bahan bakar }\end{array}$} & Pengemudi mengambil tiket pengisian bahan bakar & 0,5 \\
\hline & Pengemudi melakukan pengisian bahan bakar & 1 \\
\hline & $\begin{array}{l}\text { Pengemudi memberikan bukti pengisian dan menginformasikan ke } \\
\text { staff }\end{array}$ & 0,5 \\
\hline
\end{tabular}




\begin{tabular}{|l|l|c|}
\hline & $\begin{array}{l}\text { Staff melakukan rekap jumlah pengisian bahan bakar yang telah } \\
\text { dilakukan }\end{array}$ & 38 \\
\hline
\end{tabular}

\subsection{Gap Kondisi Aktual Dengan Proses Aturan Bank Indonesia}

Pengolahan gap proses aktual dengan proses menurut aturan Bank Indonesia adalah untuk mengetahui ketidaksesuaian yang terjadi antara proses yang dijalankan oleh Satuan Layanan dan Administrasi dan yang telah ditetapkan oleh Bank Indonesia [21], [22].

Tabel 4 Gap Kondisi Aktual Dengan Kondisi Menurut Surat Edaran Bank Indonesia

\begin{tabular}{|c|c|c|c|}
\hline Kondisi aktual & isi menurut surat edaran & Gap & Keterangan \\
\hline \multicolumn{4}{|c|}{ Proses Penyelesaian pembayaran kepada pihak ketiga } \\
\hline $\begin{array}{c}\text { masuk diterima oleh petugas } \\
\text { ekspedisi }\end{array}$ & & \begin{tabular}{|lr} 
kondisi & menurut \\
SE & tidak \\
terdapat & proses \\
surat & masuk \\
melalui & \\
Ekspedisi &
\end{tabular} & $\begin{array}{l}\text { kan penambahan } \\
\text { proses penerimaan } \\
\text { surat masuk melalui } \\
\text { ekspedisi }\end{array}$ \\
\hline $\begin{array}{c}\text { nen disampaikan dan diterima } \\
\text { oleh Kepala Perwakilan } \\
\text { untuk mendapatkan disposisi } \\
\text { dan arahan }\end{array}$ & $\begin{array}{l}\text { Perwakilan memberikan } \\
\text { disposisi dan arahan }\end{array}$ & & \\
\hline $\begin{array}{c}\text { men dari Kepala Perwakilan } \\
\text { diberikan kepada Kepala } \\
\text { Tim untuk dievaluasi } \\
\text { disposisi tersebut }\end{array}$ & $\begin{array}{c}\text { Tim menerima disposisi } \\
\text { dari Kepala Perwakilan } \\
\text { dan mengevaluasi } \\
\text { disposisi tersebut }\end{array}$ & & \\
\hline $\begin{array}{c}\text { en dari Kepala Tim diberikan } \\
\text { kepada Manajer atau Kepala } \\
\text { Satuanuntuk di evaluasi } \\
\text { disposisi tersebut dengan } \\
\text { dilakukan pengelolaan tugas } \\
\text { di SLA }\end{array}$ & $\begin{array}{c}\text { er menerima disposisi dari } \\
\text { Kepala Tim dan } \\
\text { Melakukan pengelolaan } \\
\text { SLA }\end{array}$ & & \\
\hline $\begin{array}{c}\text { Dokumen dari manajer } \\
\text { didistribusikan oleh office } \\
\text { boy }\end{array}$ & & $\begin{array}{c}\text { kondisi menurut } \\
\text { SE tidak } \\
\text { terdapat kondsi } \\
\text { yang } \\
\text { didistribusikan } \\
\text { oleh office boy }\end{array}$ & $\begin{array}{c}\text { kukan penambahan } \\
\text { proses } \\
\text { pendistribusian } \\
\text { dokumen office boy }\end{array}$ \\
\hline $\begin{array}{c}\text { nen yang telah didistribusikan } \\
\text { dan terdapat disposisi dari } \\
\text { manajer diterima staf } \\
\text { pelaksana }\end{array}$ & & $\begin{array}{c}\text { kondisi menurut } \\
\text { SE tidak } \\
\text { terdapat kondisi } \\
\text { secara detail } \\
\text { mengenai } \\
\text { pengelolaan } \\
\text { pelaksana } \\
\text { dokumen yang } \\
\text { telah diberikan } \\
\text { disposisi oleh } \\
\text { manajer/kepala } \\
\text { satuan }\end{array}$ & $\begin{array}{c}\text { kukan penambahan } \\
\text { pelaksana pengelola } \\
\text { dokumen }\end{array}$ \\
\hline
\end{tabular}




\begin{tabular}{|c|c|c|c|}
\hline sanakan proses pembayaran & $\begin{array}{c}\text { ana/Staf mengelola proses } \\
\text { pelaksanaan anggaran }\end{array}$ & & \\
\hline \multicolumn{4}{|c|}{ Proses penyediaan data } \\
\hline $\begin{array}{c}\text { masuk diterima oleh petugas } \\
\text { ekspedisi }\end{array}$ & & \begin{tabular}{|} 
kondisi menurut \\
SE tidak \\
terdapat proses \\
surat masuk \\
melalui \\
Ekspedisi
\end{tabular} & $\begin{array}{l}\text { kukan penambahan } \\
\text { proses penerimaan } \\
\text { surat masuk melalui } \\
\text { ekspedisi }\end{array}$ \\
\hline $\begin{array}{c}\text { nen disampaikan dan diterima } \\
\text { oleh Kepala Perwakilan } \\
\text { untuk mendapatkan disposisi } \\
\text { dan arahan }\end{array}$ & $\begin{array}{l}\text { Perwakilan memberikan } \\
\text { disposisi dan arahan }\end{array}$ & & \\
\hline $\begin{array}{c}\text { men dari Kepala Perwakilan } \\
\text { diberikan kepada Kepala } \\
\text { Tim untuk dievaluasi } \\
\text { disposisi tersebut }\end{array}$ & $\begin{array}{c}\text { Tim menerima disposisi } \\
\text { dari Kepala Perwakilan } \\
\text { dan mengevaluasi } \\
\text { disposisi tersebut }\end{array}$ & & \\
\hline $\begin{array}{c}\text { en dari Kepala Tim diberikan } \\
\text { kepada Manajer atau Kepala } \\
\text { Satuan untuk di evaluasi } \\
\text { disposisi tersebut dengan } \\
\text { dilakukan pengelolaan tugas } \\
\text { di SLA }\end{array}$ & $\begin{array}{c}\text { r menerima disposisi dari } \\
\text { Kepala Tim dan } \\
\text { Melakukan pengelolaan } \\
\text { SLA }\end{array}$ & & \\
\hline $\begin{array}{c}\text { Dokumen dari Manajer } \\
\text { didistribusikan oleh office } \\
\text { boy }\end{array}$ & & \begin{tabular}{|} 
kondisi menurut \\
SE tidak \\
terdapat kondisi \\
yang \\
diditribusikan \\
oleh office boy
\end{tabular} & $\begin{array}{c}\text { kukan penambahan } \\
\text { proses } \\
\text { pendistribusia n } \\
\text { dokumen oleh office } \\
\text { boy }\end{array}$ \\
\hline $\begin{array}{c}\text { nen yang telah didistribusikan } \\
\text { dan terdapat disposisi dari } \\
\text { manajer diterima staf } \\
\text { pelaksana }\end{array}$ & & \begin{tabular}{|} 
kondisi menurut \\
SE tidak \\
terdapat kondisi \\
secara detail \\
mengenai \\
pengelolaan \\
pelaksana \\
dokumen yang \\
telah diberikan \\
disposisi oleh \\
manajer/kepala \\
satuan
\end{tabular} & $\begin{array}{c}\text { kukan penambahan } \\
\text { pelaksana pengelola } \\
\text { dokumen }\end{array}$ \\
\hline anakan proses penyediaan data & $\begin{array}{c}\text { na/Staf mengelola proses } \\
\text { pelaksanaan penyediaan } \\
\text { data }\end{array}$ & & \\
\hline \multicolumn{4}{|c|}{ Proses Pengelolaan bahan bakar } \\
\hline $\begin{array}{c}\text { engisian bahan bakar diambil } \\
\text { oleh pengemudi dari staf }\end{array}$ & & $\begin{array}{c}\text { kondisi menurut } \\
\text { SE tidak }\end{array}$ & $\begin{array}{l}\text { kukan penambahan } \\
\text { proses pengambilan }\end{array}$ \\
\hline
\end{tabular}




\begin{tabular}{|c|c|c|c|}
\hline pelaksana & $\begin{array}{c}\text { terdapat proses } \\
\text { pengambilan } \\
\text { tiket pengisian }\end{array}$ & $\begin{array}{c}\text { tiket dari staf } \\
\text { pelaksana }\end{array}$ \\
\hline $\begin{array}{c}\text { kondisi menurut } \\
\text { minyak oleh pengemudi } \\
\text { SE tidak } \\
\text { terdapat proses } \\
\text { pengambilan } \\
\text { tiket pengisian } \\
\text { bahan bakar }\end{array}$ & $\begin{array}{c}\text { kukan penambahan } \\
\text { proses pengisian } \\
\text { bahan bakar }\end{array}$ \\
\hline $\begin{array}{c}\text { kannya bukti pengisian bahan } \\
\text { bakar dari pengemudi ke staf } \\
\text { pelaksana }\end{array}$ & $\begin{array}{c}\text { ondisi menurut } \\
\text { SE tidak } \\
\text { terdapat proses } \\
\text { memberikan } \\
\text { bukti pengisian } \\
\text { ke staf } \\
\text { pelaksana }\end{array}$ & $\begin{array}{c}\text { kukan penambahan } \\
\text { proses memberikan } \\
\text { staf pengisian ke }\end{array}$ \\
\hline $\begin{array}{c}\text { Staf melaksana } \\
\text { pengisian bahan bakar yang } \\
\text { telah dilakukan }\end{array}$ & $\begin{array}{c}\text { ukan pengelolaan sumber } \\
\text { daya energi }\end{array}$ & & \\
\hline
\end{tabular}

\subsection{Streamlining Proses Bisnis Berdasarkan Gap Kondisi Aktual Dengan Kondisi Menurut Surat} Edaran

Tabel 5 Streamlining Proses Bisnis berdasarkan Gap antara Kondis Aktual dengan Surat Edaran

\begin{tabular}{|c|c|c|c|c|}
\hline Proses & milik Proses & nis Aktivitas & streamlining & Analisis \\
\hline \multicolumn{5}{|c|}{ Proses Pembayaran Pihak Ketiga } \\
\hline $\begin{array}{l}\text { masuk diterima oleh } \\
\text { petugas ekspedisi }\end{array}$ & boy & & ling & $\begin{array}{l}\text { kan penambahan } \\
\text { dengan tujuan } \\
\text { meningkatkan } \\
\text { performansi } \\
\text { dalam proses } \\
\text { bisnis }\end{array}$ \\
\hline $\begin{array}{l}\text { Ien disampaikan dan } \\
\text { diterima oleh Kepala } \\
\text { Perwakilan untuk } \\
\text { mendapatkan } \\
\text { disposisi dan arahan }\end{array}$ & Perwakilan & & & \\
\hline $\begin{array}{llr}\text { nen dari } & \text { Kepala } \\
\text { Perwakilan diberikan } \\
\text { kepada } & \text { Kepala Tim } \\
\text { untuk } & \text { dievaluasi } \\
\text { disposisi tersebut }\end{array}$ & Tim & & & \\
\hline $\begin{array}{lr}\text { len dari } & \text { Kepala Tim } \\
\text { diberikan } & \text { kepada } \\
\text { Manajer } & \text { atau Kepala } \\
\text { Satuan } & \text { untuk di } \\
\text { evaluasi } & \text { disposisi } \\
\text { tersebut } & \text { dengan } \\
\text { dilakukan } & \end{array}$ & & & & \\
\hline
\end{tabular}




\begin{tabular}{|c|c|c|c|}
\hline $\begin{array}{l}\text { pengelolaan tugas di } \\
\text { SLA }\end{array}$ & & & \\
\hline $\begin{array}{l}\text { Ien dari Manajer } \\
\text { didistribusikan oleh } \\
\text { office boy }\end{array}$ & boy & ling & \begin{tabular}{|l|} 
Melakukan \\
penambahan \\
dengan tujuan \\
meningkatkan \\
performansi \\
dalam proses \\
bisnis \\
\end{tabular} \\
\hline $\begin{array}{l}\text { Ien yang telah } \\
\text { didistribusikan dan } \\
\text { terdapat disposisi } \\
\text { dari manajer diterima } \\
\text { staf pelaksana }\end{array}$ & & ling & $\begin{array}{l}\text { kan Penambahan } \\
\text { dengan tujuan } \\
\text { meningkatkan } \\
\text { performansi } \\
\text { dalam proses } \\
\text { bisnis }\end{array}$ \\
\hline \begin{tabular}{|lr} 
Inakan & proses \\
pembayaran & kepada \\
pihak ketiga & \\
\end{tabular} & & & \\
\hline \multicolumn{4}{|c|}{ Proses Penyediaan Data } \\
\hline $\begin{array}{l}\text { masuk diterima oleh } \\
\text { petugas ekspedisi }\end{array}$ & boy & ling & \begin{tabular}{|l|} 
Melakukan \\
penambahan \\
dengan tujuan \\
meningkatkan \\
performansi \\
dalam proses \\
bisnis
\end{tabular} \\
\hline $\begin{array}{l}\text { Dokumen } \\
\text { disampaikan dan } \\
\text { diterima oleh Kepala } \\
\text { Perwakilan untuk } \\
\text { mendapatkan } \\
\text { disposisi dan arahan }\end{array}$ & perwakilan & & \\
\hline 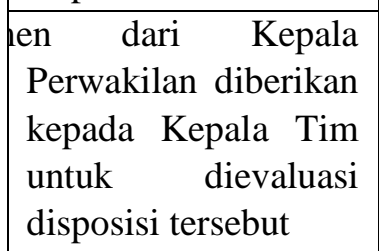 & tim & & \\
\hline $\begin{array}{lr}\text { Ien dari } & \text { Kepala Tim } \\
\text { diberikan } & \text { kepada } \\
\text { Manajer } & \text { atau } \\
\text { Kepala } \\
\text { Satuan } & \text { untuk di } \\
\text { evaluasi } & \text { disposisi } \\
\text { tersebut } & \text { dengan } \\
\text { dilakukan } & \\
\text { pengelolaan } & \text { tugas di } \\
\text { SLA } & \end{array}$ & satuan & & \\
\hline $\begin{array}{l}\text { Ien dari Manajer } \\
\text { didistribusikan oleh } \\
\text { office boy }\end{array}$ & boy & ling & $\begin{array}{l}\text { kan penambahan } \\
\text { dengan tujuan } \\
\text { meningkatkan }\end{array}$ \\
\hline
\end{tabular}




\begin{tabular}{|c|c|c|c|}
\hline & & & $\begin{array}{l}\text { performansi } \\
\text { dalam proses } \\
\text { bisnis }\end{array}$ \\
\hline $\begin{array}{l}\text { Ien yang telah } \\
\text { didistribusikan dan } \\
\text { terdapat disposisi } \\
\text { dari manajer diterima } \\
\text { staf pelaksana }\end{array}$ & & ling & $\begin{array}{l}\text { Melakukan } \\
\text { Penambahan } \\
\text { dengan tujuan } \\
\text { meningkatkan } \\
\text { performansi } \\
\text { dalam proses } \\
\text { bisnis }\end{array}$ \\
\hline $\begin{array}{l}\text { makan proses } \\
\text { penyediaan data }\end{array}$ & & & \\
\hline \multicolumn{4}{|c|}{ Proses pengelolaan bahan bakar } \\
\hline $\begin{array}{l}\text { audi mengambil tiket } \\
\text { pengisian bahan } \\
\text { bakar }\end{array}$ & hudi & ling & $\begin{array}{l}\text { Melakukan } \\
\text { penambahan } \\
\text { dengan tujuan } \\
\text { meningkatkan } \\
\text { performansi } \\
\text { dalam proses } \\
\text { bisnis }\end{array}$ \\
\hline \multicolumn{4}{|c|}{$\begin{array}{|lr|}\text { audi } & \text { melakukan } \\
\text { pengisian } & \text { bahan } \\
\text { bakar } & \end{array}$} \\
\hline $\begin{array}{l}\text { audi memberikan } \\
\text { bukti pengisian dan } \\
\text { menginformasikan ke } \\
\text { staff }\end{array}$ & hudi & ing & $\begin{array}{l}\text { Melakukan } \\
\text { penambahan } \\
\text { dengan tujuan } \\
\text { meningkatkan } \\
\text { performansi } \\
\text { dalam proses } \\
\text { bisnis }\end{array}$ \\
\hline \begin{tabular}{lr}
\multicolumn{3}{c}{ lakukan rekap jumlah } \\
pengisian bahan \\
bakar yang telah \\
dilakukan
\end{tabular} & & & \\
\hline
\end{tabular}

\subsection{Proses Bisnis Usulan}

Proses bisnis usulan diperoleh dari analisa gap antara kondisi aktual yang mengacu pada timeline Satuan Layanan dan Administrasi dan kondisi yang mengacu pada Surat Edaran Bank Indonesia.

Tabel 6 Kondisi proses bisnis usulan

\begin{tabular}{|l|l|l|l|}
\hline \multicolumn{2}{|c|}{ Urutan aktivitas } & Pembayaran Pihak Ketiga & Keterangan \\
\hline \multicolumn{2}{|c|}{ Pemberisi dan di tempat } & 1 & \\
\hline $\begin{array}{l}\text { len masuk melalui Ekspedisi } \\
\text { sekretaris }\end{array}$ & & \\
\hline een di meja Kepala Perwakilan & 1 & \\
\hline een di meja Kepala Tim & & \\
\hline
\end{tabular}




\begin{tabular}{|c|c|c|}
\hline $\begin{array}{l}\text { Ien di meja manajer unit Satuan Layanan dan } \\
\text { Administrasi }\end{array}$ & 1 & \\
\hline $\begin{array}{l}\text { Ien di catat dan dimasukkan kedalam tempat } \\
\text { khusus dokumen masuk }\end{array}$ & 5,5 & $\begin{array}{l}\text { ien yang telah dicatat akan memerikan } \\
\text { warningkepada manajer dan office boy } \\
\text { untuk segera mendistribusikan } \\
\text { dokumen tersebut sehari sebelum } \\
\text { batas yang ditentukan dari SE atau } \\
\text { berdasarkan kebijakan internal. }\end{array}$ \\
\hline Ien didistribusikan oleh office boy &, 5 & \\
\hline Ien di meja staf & 2 & \\
\hline ınaan proses pembayaran & 2 & \\
\hline Proses penyedi & aan & \\
\hline $\begin{array}{l}\text { Ien masuk melalui Ekspedisi dan ditempat } \\
\text { sekretaris }\end{array}$ & 1 & \\
\hline Ien di meja Kepala Perwakilan & 1 & \\
\hline Ien di meja Kepala Tim & 1 & \\
\hline $\begin{array}{l}\text { Ien di meja manajer unit Satuan Layanan dan } \\
\text { Administrasi }\end{array}$ & 1 & \\
\hline $\begin{array}{l}\text { Ien di catat dan dimasukkan kedalam tempat } \\
\text { khusus dokumen masuk }\end{array}$ & 5,5 & $\begin{array}{l}\text { Dokumen yang telah dicatat akan } \\
\text { memberikan warningkepada manajer } \\
\text { dan office boy untuk segera } \\
\text { mendistribusikan dokumen tersebut } \\
\text { sehari sebelum batas yang ditentukan } \\
\text { dari SE atau berdasarkan kebijakan } \\
\text { internal }\end{array}$ \\
\hline $\begin{array}{l}\text { tersebut sehari sebelum batas yang ditentukan } \\
\text { dari SE atau berdasarkan kebijakan internal }\end{array}$ &, 5 & \\
\hline Ien di meja staf & 2 & \\
\hline ınaan penyediaan data & 2 & \\
\hline Pengelolaan bal & tan $\mathrm{b}$ & \\
\hline audi mengambil tiket pengisian bahan bakar &, 5 & \\
\hline audi melakukan pengisian bahan bakar & 1 & \\
\hline $\begin{array}{l}\text { audi memberikan bukti pengisian dan } \\
\text { menginformasikan ke staff }\end{array}$ &, 5 & \\
\hline If melakukan perekapan data dalam aplikasi & 1 & $\begin{array}{l}\text { inaan rekap setiap hari harus dilakukan } \\
\text { agar data sewaktu-waktu } \\
\text { tersediadengan diatur oleh kebijakan } \\
\text { internal }\end{array}$ \\
\hline
\end{tabular}


Perbandingan waktu proses adalah untuk melihat efisiensi antara kondisi aktual dan kondisi usulan. Waktu yang digunakan membandingkan adalah waktu pada saat kondisi aktualdengan kondisi usulan, karena tujuannya adalah membandingkan proses bisnis yang terintegrasi dengan aturan Bank Indonesia.

\subsection{Efisiensi Pada Proses Bisnis Usulan}

Tabel 7 3. Efisiensi Pada Proses Bisnis Usulan

\begin{tabular}{|l|c|l|}
\hline Bisnis Usulan & Perhitungan $\left(\frac{\text { Waktu usulan }}{\text { Waktu aktual }} \times 100 \%\right)$ & siensi (\%) \\
\hline mbayaran & $\frac{44}{120} \times 100 \%$ & 36,7 \\
\hline enyediaan & $\frac{44}{120} \times 100 \%$ & 36,7 \\
\hline ngelolaan & $\frac{3}{40} \times 100 \%$ & 7,5 \\
\hline
\end{tabular}

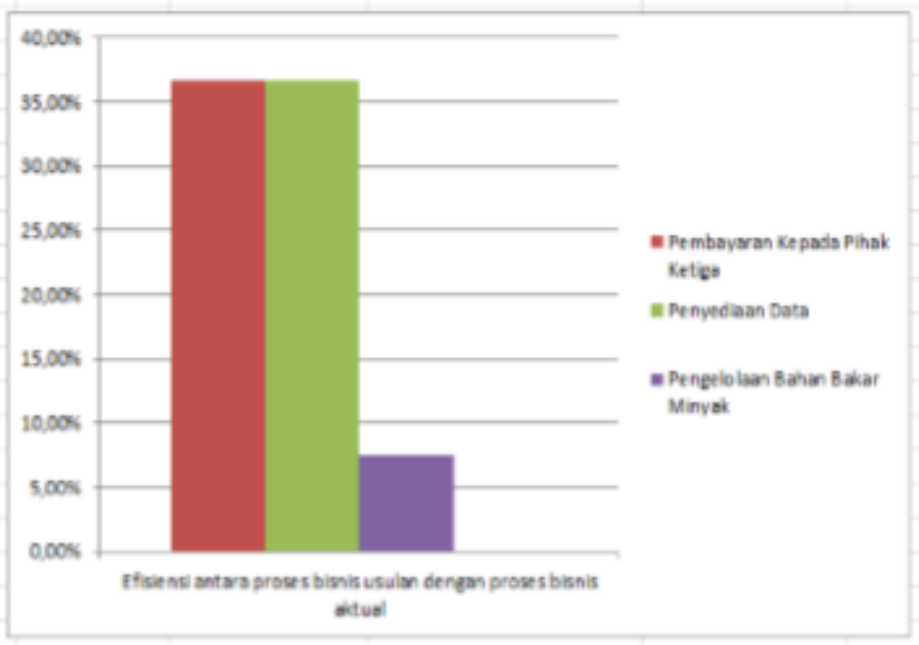

Gambar 1 Grafik Efisiensi Perubahan Waktu Proses

Efisiensi perubahan waktu proses dimana pada saat proses bisnis disilangkan antara aktual dibandingkan dengan proses bisnis usulan mempunyai efisiensi waktu proses penyelesaian untuk pembayaran pihak ketiga adalah sebesar56 jam, dan untuk penyediaan data adalah sebesar 56 jam, dan untuk pengelolaan BBM adalah sebesar $37 \mathrm{jam}$, hal tersebut setelah dilakukan analisa aktivitas dengan melakukan streamliningdengan menggunakan tool upgrading pada proses, sehingga hal ini dapat berdampak pada output yang akan dihasilkan.

\section{Kesimpulan}

1. Perbaikan proses bisnis dilakukan dengan melihat gap yang terjadi kemudian dilakukan analisis aktivitas untuk melihat proses yang memberikan nilai tambah dan proses yang tidak memberikan nilai tambah. Pada proses hasil gap dalam proses pembayaran pihak ketiga didapatkan jumlah proses yang termasuk RVA sebanyak 4 proses dan BVA sebanyak 3 proses, sedangkan pada proses penyediaan data yang termasuk proses RVA sebanyak 4 proses dan BVA sebanyak 3 proses, dan untuk proses pengelolaan bahan bakar yang termasuk aktivitas RVA terdapat 2 proses dan untuk aktivitas BVA terdapat 2 proses, Streamlining yang digunakan adalah upgrading, untuk proses yang tergolong BVA.

2. Dengan diketahuinya proses bisnis yang masuk kategori RVA, BVA maka proses bisnis tersebut dapat dilakukan efisiensi waktu dari proses bisnis aktual waktu yang diperlukan selama 120 jam kerja, sedangkan dengan proses bisnis usulan menjadi 44 jam kerja untuk proses bisnis 
pembayaran kepada pihak ketiga dan penyediaan data bagi stakeholder, sedangkan untuk pengelolaan bahan bakar proses bisnis aktual memerlukan waktu selama 40 jam kerja, sedangkan dengan proses bisnis usulan hanya memerlukan waktu 3 jam kerja, waktu pelaksanaan kerja 1 hari adalah 8 jam kerja.

3. Perbaikan proses bisnis pelaksanaan pembayaran pihak ketiga, penyediaan data dan pengelolaan bahan bakar berdasarkan Surat Edaran Bank Indonesia dan menghasilkan rancangan SOP usulan pelaksanaan proses pembayaran pihak ketiga, penyediaan data dan pengelolaan bahan bakar, SOP ini bertujuan sebagai acuan dalam pelaksanaan menjalankan proses tersebut, dengan adanya SOP ini pemilik proses dapat mengerti dan jelas aktivitas yang harus dikerjakannya

\section{Daftar Pustaka}

[1] H. Abya, M. M. Nasiri Khalili, M. Ebrahimi, and A. Movahed, "Strategic planning for tourism industry using SWOT and QSPM," Manag. Sci. Lett., 2015.

[2] R. S. Kaplan, "Conceptual Foundations of the Balanced Scorecard," Handbooks of Management Accounting Research. 2009.

[3] B. Indonesia, Publikasi Laporan Perekonomian Indonesia. Bank Indonesia, 2018.

[4] E. M. Susilowati and E. Tiningrum, "TATA KELOLA PERBANKAN DITINJAU DARI KINERJA KEUANGAN DILIHAT DARI PROFITABILITAS PERBANKAN," Ekon. Dan Perbank., 2019.

[5] M. D. Angelica et al., "Determinants of Time Allocation across the Lifespan A Theoretical Model and an Application to the," PLoS One, 2012.

[6] P. D. Pasopati, “Apa Yang Dimaksud Biaya Semivariabel ?,” dictio.id, 2017. .

[7] S. B. Utomo, "Business Process Improvement ( Bpi ) Proses Pengadaan Barang Non-Part Dengan Membangun E-Catalog ( Studi Kasus Di Pt . Tmmin )," Semin. Nas. Sist. Inf. Indones., no. November, 2018.

[8] H. C. Resende, Ayala Diego Hernando Florez, U. M. Mauricio, F. F. Antônio, and Lezana Álvaro Guillermo Rojas, "Process improvement for professionalizing non-profit organizations: BPM approach,” Bus. Process Manag. J., vol. 22, no. 3, pp. 634-658, Jan. 2016.

[9] A. Omar, "Business process management: a maturity assessment of Saudi Arabian organizations," Bus. Process Manag. J., vol. 22, no. 3, pp. 507-521, Jan. 2016.

[10] M. Hagemeister and A. Rodríguez-castellanos, "Knowledge acquisition , training, and the firm ' s performance: A theoretical model of the role of knowledge integration and knowledge options," Eur. Res. Manag. Bus. Econ., vol. 25, no. 2, pp. 48-53, 2019.

[11] M. Metz and T. Attong, "Business Process Improvement," Chang. or Die - Bus. Process Improv. Man., pp. 57-64, 2012.

[12] W. Prihatmadji, "Peningkatan dan Perbaikan dari Temuan Audit External ISO 9001 di LP3I College," Maj. Ilm. Bijak, vol. 16, no. 1, pp. 53-65, 2019.

[13] H. Anastasiya and F. Terje, "Navigating through institutional complexity: adoption of a process view in functional organizations," Bus. Process Manag. J., vol. 26, no. 2, pp. 593-612, Jan. 2019.

[14] J. Yi, G. Yuan, and C. Yoo, "The effect of the perceived risk on the adoption of the sharing economy in the tourism industry: The case of Airbnb," Inf. Process. Manag., vol. 57, no. 1, p. 102108, 2020. 
[15] A. Lumumba, G. I. Sukoco, T. Ayuningsih, I. F. Rahayu, and N. S. Toharoh, "Analisis Proses Bisnis Layanan Triple Play Menggunakan Pendekatan Business Process Improvement (BPI) (Studi Kasus di PT TELKOM INDONESIA),” J. Manaj. Indones., vol. 16, no. 3, p. 205, 2017.

[16] F. Andika, M. Kholil, T. Industri, and U. M. Jakarta, "Bussiness Process Improvement Sebagai Dasar Perbaikan Proses Penerbitan Dokumen Work Completion Certificate ( WCC ) dengan Menggunakan Metode Streamlining di PT XYZ," J. Ilm. PASTI, vol. VI, no. 1, pp. 50-57, 2017.

[17] N. Y. S. Indra Fahrizal, Ismiarta Aknuranda, "Analisis Dan Perbaikan Proses Bisnis Menggunakan Metode Business Process Improvement ( BPI ) ( Studi Kasus: PT . Wonojati Wijoyo )," J. Pengemb. Teknol. Inf. dan Ilmu Komput., vol. 2, no. 12, pp. 6201-6209, 2018.

[18] F. I. Achmad, Rispianda, and G. P. Liansari, "Business Process Improvement Untuk Proses Penjualan, Produksi Dan Pembelian di CV. Cahaya Abadi Teknik," J. Online Inst. Teknol. Nas., vol. 4, no. 01, pp. 382-393, 2016.

[19] S. D. Larasati, S. A. Wicaksono, and N. H. Wardani, "Perbaikan Proses Bisnis Menggunakan Metode Business Process Improvement ( BPI ) ( Studi Pada Bagian Riset Pemasaran dan Pusat," J. Pengemb. Teknol. Inf. dan Ilmu Komput. Univ. Brawijaya, vol. 1, no. 11, pp. 1425-1432, 2017.

[20] S. Rushanti, Y. Rohayati, and A. Aisha, "Perbaikan Proses Bisnis Penyusunan Rencana Kerja DISKOPERINDAG Menggunakan Metode Business Process Improvement Berdasarkan PERMENDAGRI Nomor 54 Tahun 2010 Serta Klausul 7.3 ISO 9001:2008," JATI UNIK J. Ilm. Tek. dan Manaj. Ind., 2017.

[21] R. Fadhillah, "Usulan Perbaikan Bisnis Proses Pada Divisi Production Engineering Di Industri Otomotif Dengan Menggunakan Pendekatan Business Process Improvement," Universitas Indonesia, 2009.

[22] N. Pröllochs and S. Feuerriegel, "Business analytics for strategic management: Identifying and assessing corporate challenges via topic modeling," Inf. Manag., vol. 57, no. 1, p. 103070, 2020. 